\section{SPRU}

Science and Technology

Policy Research
Working Paper Series SWPS 2013-09

October, 2013

\title{
Accounting for productive investment and value creation
}

Mariana Mazzucato

Alan Shipman 


\section{SPRU Working Paper Series}

The SPRU Working Paper Series aims to accelerate the public availability of the research undertaken by SPRU-associated people of all categories, and exceptionally, other research that is of considerable interest within SPRU. It presents research results that in whole or part are suitable for submission to a refereed journal, to a sponsor, to a major conference or to the editor of a book. Our intention is to provide access to early copies of SPRU research.

\section{Editors}

Tommaso Ciarli

Daniele Rotolo

\section{Associate Editors}

Florian Kern

Paul Nightingale

Matias Ramirez

Joe Tidd \&

Carlos Sato

Maria Savona \&

Mariana Mazzucato

Andrew Stirling Transitions

Caitriona McLeish

Civil military interface

Area

Energy

\section{Contact}

T.Ciarli@sussex.ac.uk

D.Rotolo@sussex.ac.uk

F.Kern@sussex.ac.uk

P.Nightingale@sussex.ac.uk

Matias.Ramirez@sussex.ac.uk

J.Tidd@sussex.ac.uk

C.E.Y.Sato@sussex.ac.uk

M.Savona@sussex.ac.uk

M.Mazzucato@sussex.ac.uk

A.C.Stirling@sussex.ac.uk

C.A.McLeish@sussex.ac.uk

J.Lieu@sussex.ac.uk

Administrator

Jenny Lieu

\section{Disclaimer}

The works available here are the responsibility of the individual author(s) and do not necessarily represent the views of other SPRU researchers. As matters of policy and practice, SPRU does not endorse individual research contributions.

\section{Guidelines for authors}

Papers shall be submitted in pdf or Word format. They should contain a title, an abstract, and keywords. Papers should be submitted to one of the Editors, who will process them and send them to the appropriate Associate Editor. Two members of SPRU will be asked to provide a short written review within three weeks. The revised versions of the paper, together with a reply to the reviewers, should be sent to the Associate Editor, who will propose to the Editors its publication on the series. When submitting the authors should indicate if the paper has already undergone peerreviewing, in which case the Associate Editors may decide to skip internal review process.

\section{Website}

SWPS: www.sussex.ac.uk/spru/research/sewps

IDEAS: ideas.repec.org/s/sru/ssewps.html 


\title{
Accounting for productive investment and value creation
}

\author{
Mariana Mazzucato* and Alan Shipman**
}

\begin{abstract}
Noting that the contribution of $R \& D$ is being integrated into national accounts just as these come under criticism for potentially overstating output, this paper uses a reassessment of the concept of value to examine scope for under- and over-statement in conventional GDP. It assesses ways in which R\&D may generate value without registering an income flow, and ways that other activities (notably financial innovation, speculation and outsourcing) might generate income without adding value; and examines equity markets' role in valuation.
\end{abstract}

Key words: value, financial crisis, growth, productive investment, rent-seeking

JEL Classification: G01 (financial crises); G32; H60; L53

Contact: *Mariana Mazzucato (m.mazzucato@sussex.ac.uk ), RM Phillips Professor of Science and Technology Policy, University of Sussex, UK. **Alan Shipman (a.shipman@open.ac.uk), Lecturer, Open University, UK. 


\section{Introduction}

The global financial crisis (GFC) that started in 2007/8 has revived a long debate on how to promote investment for long-run growth over the pursuit of short-run profits, and how to 're-balance' economies - especially the US, UK and European 'periphery' - to eliminate chronic external deficits (e.g. UKCES 2011, CBI 2011, OECD 2010a, b, 2011; Haldane and Davies, 2011). It has also intensified arguments over the capacity of the National Income and Product Accounts (NIPA) to capture accurately the size and growth of aggregate production in economies where this consists increasingly of commercial services and 'knowledge-based' products, many outsourced overseas.

Before the GFC, widely observable 'digitalisation' and 'dematerialisation' of economies led to suggestions that GDP will understate national output and growth rates, by failing to capture new forms of production associated with intangible capital (e.g. Mulgan 1997, Leadbeater 2000, Coyle 1999, Nakamura 2008, Florida 2002 Ch 3). The problem arises from the new 'creative' economy producing less measurable outputs than the manufacturing, mining, agriculture utility sectors which dominated the economies in which GDP measurement was pioneered; and from those outputs delivering value which is not fully captured in visible monetary transactions. This can lead to conventionally measured GDP understating, or omitting altogether:

-increases in output quality, when price and consumed quantity are unchanged or reduced;

-gains from product innovation that results of process and product innovation that reduce sale prices

-outputs that are not charged-for (such as freeware) and/or that deliver large external benefits (such as public artwork)

-'intangible investment' in creation/acquisition of knowledge whose commercial outcomes are uncertain (such as research and development (R\&D), and artistic endeavours)

National statistical offices and other contributors to NIPA design have been active in dealing with these criticisms. For example, the US Bureau of Economic Analysis (BEA) has since 1985 made 'hedonic' adjustments (via the GDP deflator) for quality change (Wasshausen \& Moulton 2006), and from 2013 will include R\&D and cultural production as a type of investment (BEA 2013).This latest change in national accounting reflects the trend in corporate accounting, where International Financial Reporting Standards have promoted the treatment of later-stage or acquired R\&D as an investment, rather than current expense (PwC 2010).

While these changes were still in train, however, a counter-criticism developed as a result of 'financialisation' - the growth of financial sector output and profit relative to others', and of financial activity as a contributor to the revenue and profit of nonfinancial firms. Critics have advanced the converse suggestion that conventional measurement of GDP exaggerated national output, before and possibly after the financial crisis, by:

-overstating the financial sector's value added (Haldane 2010a, Turner 2012) -counting some purely redistributive (rent-seeking) activity as productive (Turner 2012, Stiglitz 2013) 
-excluding external benefits, but including activity required solely to remediate external costs (Turner (2012), whose observation on financial instruments sold to offset the impact of speculative activity, echoes that of Mishan (1969) on 'physical' production externalities)

-ignoring a possible rise in depreciation rates, which caused net output, net investment and net value-added to rise more slowly than gross (Baker 2013) -misclassifying as 'investment' various expenditures that might more appropriately be counted as current expense, notably those on marketing and advertising to create and maintain 'intangible' assets (Gagnon \& Lexchin 2008).

The overstatement of GDP might help to explain why its growth after the late 1990s, especially in the more financialised economies, was not reflected in survey-based measures of average real incomes, which showed little growth in the decade before 2008 and declined immediately after it (Table 1). A complementary explanation is that to the extent that per-capita GDP did rise over this period, its distribution was more heavily skewed (than before 1990) towards those already on high incomes (Reich 2009:102-114, Lansley 2012:57-69). This may have been a further consequence of rentseeking activity playing a greater role in overall activity growth (Stiglitz 2013). Whereas earlier criticisms focused on ways that GDP might understate 'social' value-creation by capturing only the direct effects of enterprises' output, ignoring their external benefits, the newer criticisms identify ways in which GDP might include activities that generate private wealth in excess of social value-creation.

Table 1 Average real wage

\begin{tabular}{|l|l|l|l|l|l|l|l|l|l|l|}
\hline & 2003 & 2004 & 2005 & 2006 & 2007 & 2008 & 2009 & 2010 & 2011 & 2012 \\
\hline US & 99.8 & 100.3 & 100.0 & 100.8 & 100.0 & 102.5 & 101.2 & 101.7 & 100.7 & 100.9 \\
\hline UK & 96.1 & 98.6 & 100.0 & 101.7 & 102.1 & 102.9 & 104.2 & 101.9 & 97.5 & 95.8 \\
\hline
\end{tabular}

Source: BEA National Compensation Survey; Levy (2013)

This possibility raises questions over whether national income accounting conventions should necessarily follow those of corporate accounting, as it has in (among other cases) the capitalization of R\&D and the inclusion as assets of derivative financial instruments. Nakamura (2008:3) influentially observes that "social valuation [of intangible investments] is needed in order to explain growth, while the private valuation is needed in order to explain wealth creation." On this basis, national income accounts should present the social valuation of production, which implies the inclusion of external benefits, subtraction of external costs, ascription of value to unpriced outputs (of state and nonprofit enterprises) and omission of purely redistributive activity. External benefits (and costs) can arise across space, as when one firm's innovation allows profitable imitations or adaptations by others; and across time, as when a firm or producing region builds a lasting reputation for quality. In contrast, corporate accounts are confined to the private benefits of production: they record as production only those outputs that can be sold, and as investment only those expenditures which generate additional future revenue for the investing firm.

This paper assesses the competing claims of GDP under- or over-stating productive activity by re-examining the concept of value.-Section 1 distinguishes four value-related processes, and examines their relation to the 'gross value added' (GVA) that is central to 
GDP calculation. Section 2 applies this framework to identify ways in which national income accounting can potentially misrepresent some types of economic activity, and some necessary differences between national and company accounting procedures. Section 3 discusses the problem of value-added that does not translate into national income, focusing on research and development (R\&D) activity, and assesses the moves now under way to capitalize R\&D (and other 'intangible' investments) in national accounts. Section 4 examines some instances of the converse problem, in which income is recorded that does not derive from value-added Section 5 critically assesses the often-adopted view that value, including the present value of competing investments, can be reliably determined by equity markets, identifying problems which challenge the suggestion that such valuation is a major macroeconomic 'service' delivered by the financial sector. Section 6 draws some conclusions and policy recommendations.

\section{Value - creation, transfer, extraction, destruction}

Without departing from the conventional definition of value - as value-added in marketed production - it is useful to identify four processes that the accounting treatment of value needs to distinguish:

Value creation: Production or distribution activity generating current outputs that can be sold for more than their production costs, and/or capital assets that can generate such profitable current outputs in future

Value transfer: Income flow from one organization or individual to another, as payment for previously generated value: i.e. the realization of value creation via monetary transaction

Value extraction: Income flow generated by realising a capital gain, through selling a capital asset that was obtained through value creation or that was acquired through value transfer and underwent subsequent appreciation

Value destruction: Consumption of income gained from value extraction

In accounting terms, value creation arises from activity that generates outputs worth more than their input cost. When this output is sold, the resultant value-added appears on the income statement of the company that engages in the activity (and so contributes to national income in the macroeconomic accounts). Value creation leads to valueadded only when output is sold, recovering input cost and generating profit. There can therefore be value creation in the public sector, and the 'third sector' of non-profit institutions serving households (NPISH), which does not directly deliver value-added because the outputs are not sold. There can also be value in investment products which do not immediately produce outputs that recover their production costs, but which can do so at a later time (when they come 'onstream'), over a period of time. These 'capital assets' can include buildings, plant and equipment (physical capital), unfinished products and intermediate material (working capital), patents or copyrights from finished scientific/artistic work along with scientific/artistic work-in-progress (intellectual capital), and shares or bonds representing entitlements to income from these other types of assets (financial capital).

Value transfer is the realization of the income made possible by value creation, and/or its redistribution from one organization or individual to another. The payment of a 
profit-related bonus to employees would be an example, as would a government's transfer payments. Ordinary wage/salary payments would not be, however, as these are part of the intermediate cost that is subtracted from gross revenue to arrive at valueadded. If created value is not distributed as income (wages/salaries to employees, interest to creditors, dividends/ buybacks to shareholders, rent to landlords), it is retained within the firm in a way that can expand the assets on its balance sheet. This can occur via a straightforward value transfer, if retained profit is channeled into reserves. It can also occur more indirectly through capital gain, if retained profit is invested in (real or financial) assets. So if value transfer does not lead to consumption by the recipients, the transferred value will eventually add to the assets on a balance sheet - either of the enterprise that originally created the value, or of other enterprises or individuals to which it was transferred.

Value extraction can be thought of as the retrieval of income that resulted from previous value creation but was not immediately turned into income. This can include the realization of capital gain on a re-saleable asset; the distribution of past profit; and the liquidation of a cash reserve built up from past retained profits. The common feature of these transactions is that they represent income generated by a balance sheet change (the liquidation and running-down of assets), and not by any new value-creating activity. Where capital assets are tradable, their sale price can change in response to changing calculations of their future income-generating potential. This allows value to be extracted before any sale of products made by the activity that created the value provided there are buyers who expect those products to arise, and b profitably saleable, in future.

The income obtained from value extraction can be used to acquire new assets. This can result in value transfer if the reduction of one balance sheet is matched by expansions of others, and in value creation if the income funds new value-adding activity. The 'Boston Matrix' suggested that large conglomerates' 'internal capital markets' could extract value from cash-rich, slow-growing 'sunset' units to re-invest in its cash-hungry fastgrowing 'sunrise' units. External capital markets were later judged more efficient at making such reallocations, resulting in the break-up of many conglomerates. But the underlying logic remains the same: 'mature' enterprises that expanded in the past but have run out of growth opportunities will accumulate balance-sheet resources that can fund new value-creating activity if extracted and transferred.

However, the income obtained from value extraction can also be directly consumed (by spending it on consumer goods and services), or indirectly consumed (by using it to acquire real or financial assets that do not generate a return). This using-up of income results in value destruction, since there is no acquisition of new assets to offset the running-down of assets that generated the income.

\section{National accounting problems arising from value creation and destruction}

The four value-related processes have been identified at enterprise level, so will typically be first identified in corporate accounts. The task for NIPA is to aggregate them so that income generated by value-creating activity appears on the national income statement (IS), asset accumulation or decumulation appears on the national balance sheet (BS), and redistributive flows if income appear on the flow-of-funds account (FF). 
Table 2 summarises the value-related processes and shows their relation to these three NIPA components.

Table 2 Accounting treatment of value creation, transfer, extraction and destruction

\begin{tabular}{|l|l|l|l|}
\hline & What appears on IS & $\begin{array}{l}\text { What can also occur } \\
\text { as FF }\end{array}$ & $\begin{array}{l}\text { What can appear on } \\
\text { BS }\end{array}$ \\
\hline Value Creation & $\begin{array}{l}\text { Activity } \\
\text { generating } \\
\text { outputs that can } \\
\text { sell for more than } \\
\text { the cost of their } \\
\text { inputs, now or in } \\
\text { future }\end{array}$ & $\begin{array}{l}\text { Unrealised capital } \\
\text { gain, from } \\
\text { appreciation of } \\
\text { output or } \\
\text { intermediate input } \\
\text { before sale }\end{array}$ & $\begin{array}{l}\text { Equity increase via } \\
\text { new asset } \\
\text { acquisition and/or } \\
\text { revaluation }\end{array}$ \\
\hline Value Transfer & $\begin{array}{l}\text { Proceeds, from sale } \\
\text { of output for more } \\
\text { than input cost, } \\
\text { passed from one } \\
\text { agent to another }\end{array}$ & $\begin{array}{l}\text { Income transfer } \\
\text { between producer } \\
\text { and consumer, or } \\
\text { profit transfer } \\
\text { between company } \\
\text { units, due to price } \\
\text { change }\end{array}$ & $\begin{array}{l}\text { Equity increase via } \\
\text { new asset } \\
\text { acquisition and/or } \\
\text { revaluation }\end{array}$ \\
\hline Value Extraction & $\begin{array}{l}\text { Income generated } \\
\text { from previous } \\
\text { (productive or } \\
\text { speculative) } \\
\text { capital gain }\end{array}$ & $\begin{array}{l}\text { Realised } \\
\text { (productive / } \\
\text { speculative) capital } \\
\text { gain }\end{array}$ & $\begin{array}{l}\text { into money; assets } \\
\text { unchanged or } \\
\text { increased if re- } \\
\text { invested efficiently }\end{array}$ \\
\hline Value Destruction & $\begin{array}{l}\text { Consumption of } \\
\text { income gained via } \\
\text { value creation, } \\
\text { transfer or } \\
\text { extraction }\end{array}$ & $\begin{array}{l}\text { 'Productive' or } \\
\text { speculative' capital } \\
\text { loss }\end{array}$ & $\begin{array}{l}\text { Equity converted } \\
\text { into money and } \\
\text { spent; assets } \\
\text { reduced }\end{array}$ \\
\hline
\end{tabular}

IS Income statement FF Flow of Funds BS Balance Sheet

The bold entries in Table 2 indicate potential problems for conventional national income accounting - in the form of additions to GDP that don't actually arise from the value-adding process it is supposed to measure, or value-adding processes that don't get counted as additions to GDP.

At the value creation stage, some income flows can enter GDP even though they merely represent cost, with no indication that the activity generates income that equals or exceeds this, because there has not yet been a transaction that realises the value. (Interest payments for 'capital services', one of the principal ways in which banks are assumed to add value, are one important example highlighted by the GFC). As defined, value creation creates only the potential for this problem, because no value is realised until output is sold; but the problem is actualised when sale takes place.

Value transfer, intended to be wholly excluded from value-added because it simply reassigns income (and may consume some due to administrative cost), can in practice be 
part of an activity that registers in GDP. Gambling activity, including speculation on real or financial assets, is in principle excluded because gains are matched by losses. But when a transfer takes place over time, as well as between agents, value created in one year can register in enterprise (and national) income in another. This occurs, for example, when undistributed profits build up on a balance sheet, as reserves or shareholders' equity, becoming available for 'release' at a later date through distribution to shareholders or advancement as security for a loan. When a transfer occurs through a change in market prices, it may register as a value-added increase even without a lapse of time. This can occur, for example, when increased market power (and price-inelastic demand) allow a company to raise its mark-up over production costs, or when 'transfer pricing' is used to move profits offshore for the avoidance of tax liability.

Value extraction can enter GDP, against the intentions of the NIPA designers, if an income flow that originates from asset appreciation (capital gain) is ascribed to production activity. Examples would include an oil firm that produced nothing in the year but realised a profit from the price gain on its existing stocks; a start-up company that is still at the pre-production stage but made profits from flotation; a large mutual or family-owned company that uses flotation to 'release' accumulated equity and distribute it to the new shareholders; or an investment bank whose only profits came from cashing-in on its gains from stock trading. Such capital gains are intentionally excluded from the NIPA, which aim to record only income generated by productive activity during the period. The 'Hicksian definition' (also associated with Haig and Simon) of individual and national income, as all that can be spent in a period without diminishing wealth, was rejected early in the NIPA design (Stone 1984). This accords with corporate accounting convention, which distinguishes income ascribed to balancesheet evaluation from that generated through current production activity.

However, value extraction can give rise to correctly-recorded GDP increase when it makes more resources available for value-creating activity, or promotes more valuecreation from the same resources. The argument is similar to that regarding rentseeking, a 'directly unproductive' redistribution of income which may become 'indirectly productive' because of the use to which the income is subsequently put. Rentseeking can be indirectly productive when the prospect of rent, arising from market power, gives an incentive for investment or innovation.

Such benefits are likely to be time-limited: if the barriers to entry and higher than average profit lasts too long, rent extraction ceases to be productive and can promote 'unproductive entrepreneurship' (Baumol 1990). Rent-seeking's social costs can escalate because everyone has an incentive to spend, on creating arrangements that capture rent, up to the value of the rents they expect to extract if their quest is successful. Critics of economic regulation have tended to argue that rent-seeking becomes unproductive when it (a) involves the creation of permanent entry barriers (and monopoly powers) in the private sector, or (b) when it involves political activity aimed solely at redistributing income (Buchanan 1980, Ekelund \& Tollison 1981). As political activity often involves lobbying to achieve a durable monopoly through political regulation, (b) is often a step towards (a).

Although it is often assumed that competition and contestability will erode the profits of entrepreneurship before it becomes unproductive (hence their designation as 'quasirents'), it is not clear that the productive/unproductive distinction coincides with the 
distinction between rent-seeking confined to the private sector and rent-seeking that resorts to political or legal intervention in market processes. A more informative division is between rent-seeking that captures profit from an additional set of transactions, and rent-seeking that also capitalizes unrealized profits from past transactions (Mazzucato \& Lazonick 2012). The 'Schumpeterian' capture of marginal rent rewards risk-taking innovation, and can therefore incentivize value creation. But investor rewards can substantially outweigh the Schumpeterian when claims on real assets undergo sudden large revaluation on financial markets (Thurow 1975). This highlights the need for a dynamic understanding of how policies can 'shape' markets so they limit rent seeking and unproductive investments (Burlamaqui, 2012).

While value extraction may be at least indirectly productive, value destruction is a consumption activity that makes no direct contribution to production. The accumulation and release of balance-sheet equity or reserves merely redistributes value-added and GDP across time. Income generated in the process of value destruction can, however, still enter GDP, when it results in expenditure on final outputs that is recorded as if generated by the activity that produced those final outputs.

This review of the accounting treatment of value processes highlights two areas of particular concern:

-the recording of income (in corporate and national accounts) that does not arise from value-added activity

-value-added activity that does not result in the recording of income (in corporate or national accounts)

The next two sections analyse examples of these in more detail.

\section{Value creation without income: the treatment of R\&D}

Value creation does not lead to value-added until its outputs are sold at profit. Until such sale, expenditure on productive activity is classified as investment - in the 'working capital' of unfinished products and undelivered services, and/or the 'fixed capital' of plant and machinery that can generate a future flow of saleable output. Corporate accounts have traditionally allowed for this delayed conversion of inputs into saleable outputs by showing investment as an addition to balance sheet assets. Firms can then capitalize investment, and spread it across the lifetime of the acquired assets, rather than expensing the full cost in the year of acquisition. Expenditure on maintenance and replacement of capital assets is likewise spread across their lifetime, through annual contributions to depreciation and amortization. While there has been lively argument about the appropriate lifetime to ascribe to different types physical capital, the principles behind accounting treatment of investment have rarely been an issue at company-accounting level.

However, R\&D and other expenditures on 'intangible' assets have not always been treated as investment. Although some national accounting systems allowed them to be capitalised in the past, the convention under most (including US Generally Agreed Accounting Practice, GAAP) was until recently for all R\&D to be expensed. This reflected the general principle that whereas investment will lead to an asset that is intended (and likely) to generate future income, there is no assurance that 'basic' R\&D will ever do so; and even 'applied', later-stage R\&D will often fail to yield any physical or intellectual property that can generate a commercial output. For these reasons, R\&D) was 
traditionally treated as intermediate consumption, and part of general production cost. Even after recent changes (starting with European-generated International Financial Reporting Standards, IFRS, and subsequently applied to US GAAP), capitalisation is usually applied only to R\&D expenditures involving later-stage development (when an income-generating asset is on the horizon), or acquisition of rights to a later-stage technology (PwC 2010).

The movement towards a more widely permitted capitalization of $R \& D$ is in part a recognition that the contrast may have been exaggerated. All investments, including those that merely replicate existing, profitably-operating capital equipment, run the risk that they will not yield new assets whose returns exceed their costs. But the change was also prompted by perception that R\&D was being undervalued by external investors, putting R\&D-intensive firms at a commercial disadvantage, and that this undervaluation was linked to the expensing requirement (which reduces current profit when R\&D spending is increased). Studies in a variety of countries have shown that R\&D spending has an adverse impact on stock-market valuation and earnings risk compared with equivalent investment spending, and that a switch from expensing to capitalizing $R \& D$ raises market valuation (e.g. Kothari et al 2002, Ciftci et al 2011, Tsoligkas \& Tsalavoutas 2011). This occurs despite widespread tax incentives for R\&D, which may encourage firms to classify other (including marketing) expenditures under this heading, and the tendency even in R\&D-intensive industries such as pharmaceuticals to favour late-stage R\&D (often involving minor modification) over the more uncertain early-stage 'fundamental' research (Light \& Lexchin 2012).

At macroeconomic level, the omission of R\&D from measured NIPA investment became a source of increasing concern to economists as post-war growth accounting shifted the explanation of real GDP increase from capital accumulation to technical progress (e.g. Solow 1957, Romer 1994). In response, national statistical offices including the BEA have developed 'satellite' accounts detailing R\&D investment, and are now integrating these with the main national accounts. R\&D and other 'intangible' investments will now be valued in a comparable way to physical capital investments, and subject to the same set of measurement issues. The present value of the gross capital stock can be calculated retrospectively as the sum of past gross investment flows, each deflated by the appropriate inflation index. The net capital stock can be derived by allowing for the depreciation of each year's investment, due to wear and obsolescence (Scott 1989:9091). So, for example, the BEA will calculate past gross R\&D outlays from various national Science Foundation surveys, derive their present value by applying an alreadydeveloped $R \& D$ price index, and apply 'R\&D depreciation rates' based on the measured relationship between R\&D spending and subsequent profits in different sectors (BEA 2013: 15-17).

The agency regards its approach as deliberately conservative. Only the direct effects of R\&D on capital stock income will be counted (Fixler 2009:2), even though the external benefits of successful innovation are acknowledged to be large, especially when there is no (or short-lived) intellectual property protection to slow the diffusion of new ideas. R\&D fixed assets will be depreciated in the same way as other fixed investments (BEA 2013:16), even though some embody knowledge whose value does not decline with passage of time or with diffusion to other users: studies that find an 11-year average service life for R\&D output are mainly based on surveys of ideas with intellectual property protection, which is only requested for ideas that have a depreciation risk 
(Fixler 2009:5). The price deflator applied to R\&D will be significantly higher than the GDP deflator (averaging 7.1\%/year for 1987-2006) (Copeland \& Fixler 2012).

R\&D outputs will be measured from expenditure on inputs, even though research periodically leads to commercial outputs that vastly exceed the cost of the inputs. Crick and Watson's 'double helix' insight, Black and Scholes's option pricing formula and Berners-Lee's Worldwide Web design gave rise to value-added somewhat in excess of their salaries and laboratory costs, even after adding those of the earlier research on which they drew. Such examples are a significant counterweight to the failed R\&D projects that absorb costly inputs and produce no output - especially if some of these prove to be indirectly productive by revealing lines-of-enquiry to be avoided. Because of the durability of commercial knowledge - which loses its private wealth-creating potential but gains in social value-creating potential when patents and other protections expire - it is open to debate whether any depreciation should be applied to capitalized R\&D. Scott (1989: 19-33) makes the case that gross investment is the relevant measure when accounting for growth, because depreciation is merely a redistribution (from capital to labour) - value extraction and transfer, but not the capital consumption that would lead to value destruction. This argument may have been sidelined by Scott's very broad definition of investment, as "expenditures undertaken to improve assets... rearrangements of things or of systems of work" (1989:14); but as this accords very closely with concepts of $R \& D$, the concept of depreciating $R \& D$ outputs remains problematic.

In consequence, the capitalization of $R \& D$ and of cultural products in the US is expected to add around 3\% to currently-measured GDP, which will be backdated to 1929 to avoid disruption to the series (Irwin 2013). Although substantial in absolute terms, the increase is likely to be viewed as comparatively small given the substantial contribution ascribed to R\&D in neoclassical growth accounting. As few other economies match the US scale of combined business and government R\&D, or its apparent productivity (Mazzucato 2011: Ch 4), few are likely to record a proportionally bigger GDP rise if they implement the same changes. Difficulty of integrating the value-creation inherent in R\&D with the value-added basis of national income may help explain the limited impact of the accounting change now being introduced.

'Diffusive' investments, which contribute to a positive return on collective (industry) investment while yielding negative returns for the individual investor, are the sometimes neglected inverse of 'crystalizing' investments, which yield a positive return for the individual while making a zero or negative contribution to collective investment returns. The tendency to appraise investment from an individual agent perspective, fundamental to advances in financial theory, has inevitably distanced it from analysis of value, an emergent phenomenon not easily reduced to micro-foundations. Value is created by investment that re-arranges resources for profitable sale (production), that identifies profitable new combinations of resources (e.g. research and development), that moves products to places or into forms where they are worth more (distribution), and that re-arranges existing corporate resources for increased production and productivity (restructuring/turnaround). Value is not necessarily created by investment that merely 'revalues' existing products or corporate resources by buying and later reselling them in unchanged form. Such investment - typified by speculative trading in financial instruments and property - can generate a return for the investor without creating new value, and so involves the redistribution of income and resources rather 
than their new creation. There can be a temporal as well as a spatial dimension to the disconnection of returns from the agents whose risk-taking enabled them. Value is not necessarily realized at the time it is created; indeed, disruptive major innovations may lead to financial crises, which cause asset values to fall sharply, before the growth potential of the new technology is fully realized under new organizational structures and regulations (Perez, 2012).

The potential disconnection between those who take risks and those receiving the consequent returns, and between individual and social returns, adds to the problem of subjectivity (in projections of future costs, revenues and time preferences) that already arises in conventional investment appraisals. Economists have often resolved these problems by taking a procedural (rather than consequentialist) approach to appraisal, judging the provenance of an investment to judge its productiveness. It is (ideologically) assumed to be productive if private investors subscribe all or most of the capital and absorb all or most of the risk; unproductive if heavily state-financed and state-directed (e.g. Boaz and Crane, 1993; Bacon and Eltis, 1976). Build-up of debt is viewed as more sustainable if incurred by the private rather than the public sector, and external deficits are assumed benign if linked to private- rather than public-sector deficits. This straightforward division is challenged, however, by the substantial misdirection of private investment exposed by the asset price collapse of 2008-9, and private investors' inability to absorb it, with consequent social costs arising from bail-out funding as well as GDP loss (Haldane 2010b).

\section{Income without value creation: speculation, financial intermediation, outsourcing}

National income accounting has been designed to exclude income that does not originate from value-added activity. But some instances of income generation without value creation, observable at microeconomic level, may be carried over into national accounts - especially in the cases of speculative asset trading, financial intermediation and offshore outsourcing, explored in the next three sections.

\subsection{Speculation and equity withdrawal}

Speculation can be defined as the profitable re-sale of purchased items without performing any activity except the exercise of ownership (and possibly storage). Such items can include raw and intermediate materials (working capital), final outputs, physical capital, financial instruments, real estate, and companies bought and sold through equity holding. Speculative trading gains may be made deliberately, by traders who set out to 'buy low and sell high' (or to short-sell and repurchase) without making any intention to improve the income-generating capacity of what they transact in (Benabou, 1989; Lewitt, 2010). They may also be made accidentally by those engaged in value-added activity, when the resale prices of raw materials or finished outputs rise between the time of their purchase and the time that final output is sold.

Like rent-seeking, speculation may have a productive outcome (and a GDP contribution) despite its zero-sum appearance. A firm whose inputs rise in resale price between the time of purchase and of finished-product sale, and which passes on the increase, may enjoy an addition to value-added part of which is effectively speculative gain. A financial 'marketmaker' buys when all others are selling, hoping to re-sell when prices have 
risen, but thereby provides a useful service (market liquidity) despite the appearance of speculation. But however they arise, the rewards to speculation and stock appreciation are counted as a capital gain, not as generation of new income, in national accounts (Stone, 1984).

Equity withdrawal is the paying-out, as income, of assets previously 'stored' on a balance sheet as a result of previous income generation that led to asset accumulation. Some of the released equity may have arisen from previous capital gains (for example, appreciation of a company's share price due to its improving profit-generation prospects), so would count towards income under the 'Hicksian' definition (the maximum that can be spent while keeping wealth intact). However, NIPA conventions adopt the narrower value-added definition of income; and when equity is withdrawn at a later date, after being added to the asset side of a balance sheet, this represents a deduction from wealth that would also be excluded under the Hicksian definition.

In practice, the exclusion of both types of 'unearned' income from national accounts is difficult to maintain. The value-added measure that underlies GDP measurement does not distinguish sustainable income flows (which add to a stock of assets or leave it unchanged) from unsustainable flows (which deplete a stock). So large, one-off equityreleases attained by securitizing debt, floating family/mutually/cooperatively owned firms on the stock market, and cashing-in (or securing debts against) past balance-sheet appreciations appear to have positively impacted GDP growth in the 1990s and early 2000s, despite these being one-off flows that turned out eminently reversible. National income accounting is not immune to a 'capitalization' of capital gains that inverts the usual process of adding value. Instead of a production activity whose profit adds to balance sheet reserves, it represents a removal of balance-sheet reserves which generates profit, without any change in production.

\subsection{Financial intermediation services}

The risk of speculative gains being classified as national income gains appears to have risen with the expansion of the wholesale financial sector. Today's SNA still rests on a foundation built at the start of the 'Bretton Woods' era, when regulation kept financial sectors small and promoted a separation of real investment (in production and delivery of goods and services) from financial investment (in the instruments that finance real investment). That separation has been eroded by the growth of the financial sector and extension of its activity beyond financial services sold for transparent fees - requiring changes in accounting practice to capture value-added by mobilising funds for investment and by trading in financial instruments. Since the GFC, some prominent observers of the financial sector (eg Haldane 2010a, Turner 2012, Kay 2012, Stiglitz 2013) have raised fundamental questions about the measurement of value-added in financial services, particularly raising the possibility of:

- exaggeration of the contribution to production of financially risky activities, due to understatement of the risks (causing overstatement of investment returns); - mis-classification of some intermediate consumption as final production, so that it is included in the value-added measure when it should be subtracted.

Until 2007 there seemed to be a consensus that economic growth requires 'financial deepening' - an expansion of the financial sector's share of (and ratio of money supply 
to) GDP, and that such deepening required the removal of interest-rate caps and other capital controls (Shaw 1973, Mackinnon 1973, Kiyotaki \& Moore 2005). The rising share of financial services in GDP, across the OECD and notably in the UK and US, was therefore viewed as conducive to the growth of GDP. Expansion of banks and financial markets was assumed to enable non-financial companies to lower their capital costs and lay-off risks, by (among other contributions):

*Improving the allocation of savings to investment, and generating more savings to finance investment

*Lowering the costs of issuing bonds and shares by creating more liquid markets for them

*Lowering the transaction cost of retrading bonds and shares, through larger and more competitive secondary markets

*Reducing non-financial companies' risk by creating (and deepening) futures and options markets

*Allowing more efficient and cheaper hedging of interest and exchange rates

*Reducing creditors' risk by creating credit default swap markets

Some of these functions involve the provision of markets and supporting services where none previously existed, and mobilization of capital for investment that was previously unavailable. The resultant expansion of output can explain why a more efficient financial sector should be a larger one (in relation to GDP), in contrast to other sectors (such as agriculture and textiles) where efficiency improvement has led to a declining GDP share. In addition, most larger financial sectors (including those of the UK and US) channel substantial business from abroad, generating significant export earnings, so their growth as a proportion of GDP can be regarded as revealing comparative advantage. However, the unusually strong rise in financial sector GVA in the years before the crisis has raised important questions over whether this was being appropriately measured, and/or was an appropriate measure of the sector's contribution.

Haldane (2010a) highlights the extent to which financial firms' GDP contribution was enlarged from the late 1990s by the widening gap between their average interest rate to lenders and the rate at which they could borrow - a premium which, since 1993, has been treated as showing banks' contribution to GDP through 'financial intermediation services indirectly measured' (FISIM). After 2008 it transpired that banks' borrowing costs had been artificially low, because all had ben underestimating their risks and the largest had enjoyed an explicit state guarantee through being 'too big to fail' (ICB 2011). But the immediate impact of financial crisis was to widen the premium further, as banks raise their interest rates to commercial borrowers while the central bank held down their own funding costs. This had the perverse result of lifting UK banks' GVA at its fastest-ever pace in 2008Q4, a time when they were universally recognized to be in crisis (Haldane 2010a: 3). Figure 1 shows the sudden spurt in financial compared with non-financial GVA, immediately before the 2008-9 crash. 
Figure 1 Financial intermediation and aggregate gross value added compared

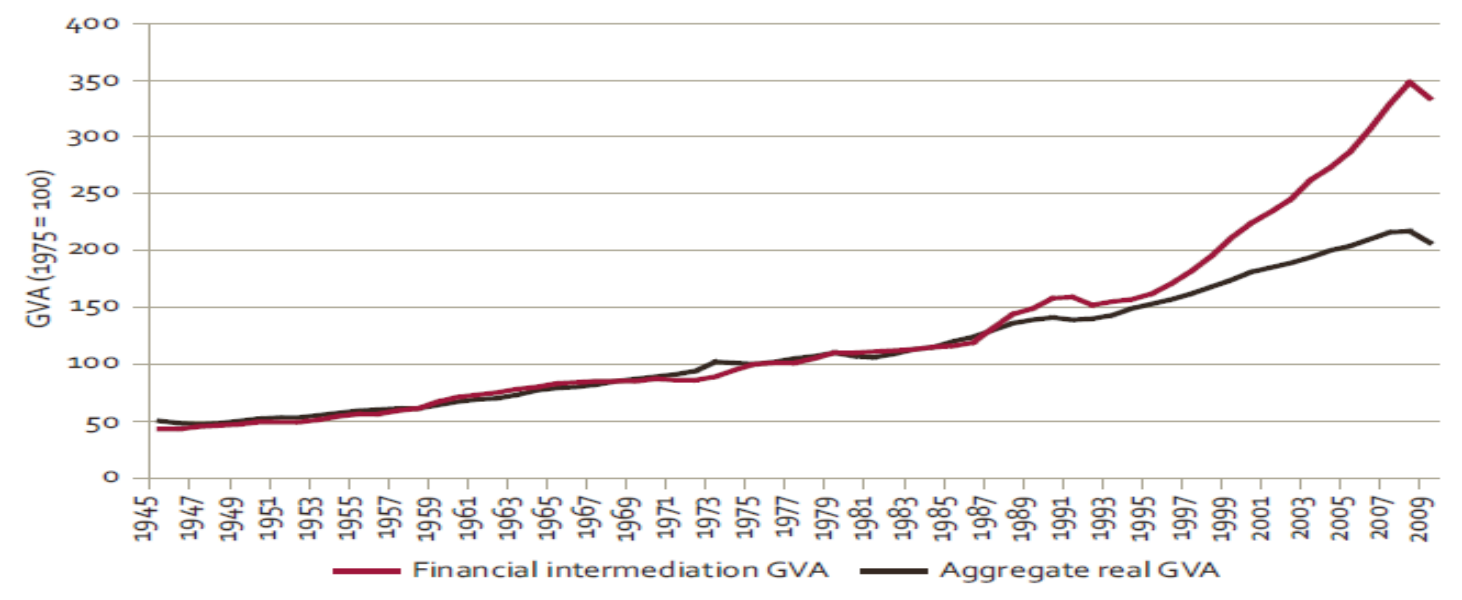

Source: Alessandri and Haldane (2009)

Banks had already lifted their GVA and profit rate far faster than most other industrial and service sectors, by making riskier loans and securities trades and by extending their leverage, so as to multiply capital gains. Their return on equity (ROE, the measure most of interest to shareholders) expanded faster than their return on assets ROA), which was held down by the growing scale (and risk) of assets. Since GVA rose without significant growth in labour or capital employed, banking seemed to achieve a totalfactor-productivity 'miracle' (Haldane 2010a: 11-12). Haldane argues that these exaggerations of banks' GVA would have been largely avoided if the banks' interest-rate differential had been adjusted to take account of the increased risk of the loans they were making to attain a higher yield (by, for example, measuring the premium over rates on comparably risky borrowings, rather than over a risk-free rate). But the FISIM controversy highlights the possibility of GDP becoming seriously distorted when a cost of production is mis-classified as an output, and included in the value-added measure when it should be subtracted.

\subsection{Outsourcing}

Outsourcing - the external purchasing intermediate goods or services, including labour and capital services, that were previously produced in-house - may be a further source of GVA increases which do not reflect any change in real activity. Because it reduces intermediate cost, successful outsourcing contributes to GDP growth, as well as to the profitability of manufacturers and service companies that engage in it. The gains can be especially significant when production stages are 'offshored' to overseas subcontractors. In the public sector, outsourcing current operations to specialist service providers has become a principal strategy for reducing cost, and outsourcing capital projects to private companies to defer the treasury cost of the investment, as well as (in some cases) to transfer its risk. 
Although successful outsourcing reduces the cost of intermediate inputs, without reducing the sale price of the output, it is not clear that this is the value-added equivalent of reducing production cost through process innovation (or of enabling a higher output price through quality improvement and product innovation). It might be more correctly interpreted as the effect of a price change, raising GVA through lower input cost in the same way that additional market power can raise GVA through higher output cost. The effects of price changes are normally eliminated at macroeconomic level, through the application of GDP deflators. Studying outsourcing in the context of financial deregulation and capital-account openness, Vlachos and Waldenstrom (2005) find that financial liberalization is associated with growth in industries' real output, without any measured rise in value-added. In this case, the effect of price changes is removed by a fall in final output prices, due either to competition or (their preferred explanation) to long-distance outsourcing. "If the setting up of new plants is made less expensive by the liberalization of financial markets, firms become more inclined to outsource parts of their production. Since outsourcing means breaking up value-added chains, it could result in a pattern of increased firm creation, increased measured output and zero growth in value-added," (Vlachos and Waldenstrom 2005; 263-4).

The implication is that measured output (and GDP) growth arising from outsourcing can be deceptive, since with no change in value-added - and an intention of reducing the quantity or cost of inputs - it is unclear where the growth would come from. Commercial confidentiality surrounding many outsourcing contracts makes it difficult to assess the practical impact. But the main implication is that conventional output and value-added measures may show a private and social return on outsourcing investment even when this only changes the location or ownership of a production stage, without altering the process itself.

\section{Re-thinking stock-market valuation}

The analysis presented so far strongly supports Nakamura's (2008) distinction between the private wealth creation recorded in corporate accounts and the social value creation that National Income and Product Accounts are intended to record. It suggests that NIPA may continue leave out significant sources of value-added that are not translated in to income, even after R\&D and cultural products are included using the methods now being introduced. At the same time, NIPA may continue to include significant income that do not arise from value-added, especially those associated with the financial sector.

As well as accounting measures based on past investment expenditure, most economies have a 'market' measure of their privately-owned capital stock through financial markets, and the value they place on companies' equity. This in principle measures the present value of profits on future output, discounted at a rate which adequately captures the associated risk. However, the studies questioning markets' ability to evaluate R\&D, cited in section 3, are complemented by a number of others that question the general efficiency of stock markets in assigning valuations (e.g. Shiller 2005:177192). While some published studies have found stock-market valuations to be unaffected by the choice between capitalization and expensing (e.g. Chan et al 2007), most have found equally R\&D-intensive firms to enjoy a stock-price advantage if they use capitalization. This helps to explain why R\&D-intensive firms (and their industry associations) stepped up pressure for accounting rules to be changed in this direction, 
as they came under greater value-maximising pressure from activist shareholders and takeover threats.

\section{1 'Short-termism' in appraising future value}

The long-held concern that market valuations are distorted by excessive discounting, reflecting a 'short-termist' perspective among equity investors (Miles 1993), has been reinforced by recent stock-market studies, notably the Kay Review (Kay 2012). This identifies a tendency of stock-market-quoted firms to under-invest in physical and intangible assets (including product development, employee skills and reputation), and to focus excessively on "restructuring, financial re-engineering or mergers and acquisitions at the expense of developing the fundamental operational capabilities of the business" (Kay 2012: 10). In the terms developed here, this means a focus on value transfer and extraction at the expense of value creation. This problem of managerial behaviour is traced back through the "equity investment chain" to asset managers who compete on short-term relative performance, and are therefore driven to hold stocks in firms that do the same.

The period over which investment returns are measured, and the discount rate applied to them, can substantially alter the evaluation of different projects. It is well-known that high discount rates, imposed by preference for rapid payback, will favor projects which generate early revenues and whose capital costs are either low or displaced into the future, The ROI requirements now placed on most equity investment (private as well as public) are inconsistent with the long intervals usually needed to develop value-adding innovations in industries such as electronics and pharmaceuticals (Lazonick and Tulum, 2011; Lewitt, 2010). While it could still be argued that stock market valuations are more accurate than any alternatives, these markets are primarily a device for valuing existing assets and re-trading entitlements to their returns. Capital for new investment is raised only when companies make initial public offerings or issue new bonds or shares. Even in this case, some of the funds raised represent a value transfer from new (public) to existing (private) investors, which may be followed by value extraction as earlier loans are repaid and shareholdings cashed-in.

Returns on equity were substantially raised (across most OECD stock markets) in the decade to 2008 by increases in banks' and corporates' leverage, which inflated the prices of remaining corporate equity and the consequent return on equity investment, while leaving the financial system increasingly fragile (Turner, 2009; Lewitt, 2010). Significant substitution of equity for debt is now being imposed on banks, under new international (Basel III) and national regulations. However, the relaxation of monetary policy has relieved corporates of similar pressure: some have continued to reduce their equity through share buybacks, which reached new peaks after 2008 (Lazonick, 2009), others have chosen to accumulate cash. The stock market's role in new equity raising has been compromised by the rising discount rate and shortening payback period that it appears to have imposed on listed companies (especially those with higher leverage) since the mid-1990s (Haldane and Davies, 2011), as well as by the growth of private equity and its gradual extension (via leverage) to larger companies taken private through management buyouts. Understanding the strengths and limitations of public equity markets is essential for promoting productive capital allocation. 


\subsection{The changed nature of 'equity'}

The creation of joint-stock companies with limited liability was arguably one of the greatest financial innovations. Allowing companies to issue shares to outside investors meant that top executives could be recruited for their management skill, irrespective of their ability to contribute financially. The re-tradability of shares made it safer to invest, and reduced the cost of equity capital. The insertion of 'shareholders' equity' as a wedge between companies' (and banks') assets and liabilities made them financially more stable, by enabling them to withstand a fall in asset value (or rise in liabilities) without losing solvency. Share issuance made it easier and cheaper for firms to borrow, because a public company struggling to repay its debts could dip into shareholders' equity to stay afloat.

However, the nature of shareholders has changed radically since the inception (in the UK) of joint-stock companies, or PLCs. Most UK-based shareholders (who own around half of UK equity on the London Stock Exchange) are now institutions, not risk-taking individuals. These institutions are mainly pension and insurance funds, whose appetite for risk is strictly limited. There is pressure on these institutions to deliver high returns, especially as pension funds face increased withdrawals in an ageing society and insurance funds are required to offset the competitive erosion of profitability on premiums. But institutional funds must also safeguard subscribers' capital, and keep their investments sufficiently liquid to meet unexpected withdrawals. So most run riskaverse portfolios weighted towards AAA-rated government bonds and 'blue chip' equities, with only a small proportion in high-risk asset classes such as small-firm equity and emerging markets. The rapid shrinkage of AAA-rated sovereigns since 2008, especially in Europe, has set back attempts to recapitalize the banks and revealed potential fragility among insurers for the first time.

One consequence of this is that very little of the capital that investors subscribe to institutional funds makes its way into small and medium-scale enterprises (SMEs), and only a small proportion of this goes to the $6 \%$ of innovative SMEs that generate growth and create jobs (NESTA, 2009). Most is lent to government (via bond issues), or buys the existing shares of large 'blue chip' companies with reliable earnings but generally slow growth. These companies finance most of their new investment out of profit retentions. But they will only proceed with projects if the expected return exceeds the rate that that shareholders would receive if the profit were distributed as dividend, by a premium that compensates shareholders for the projects' perceived risk. Internal financing of investment is a reaction to cost penalties imposed on externally raised funds, and its expansion is consistent with the growing cost penalty applied by financial markets to longer-term capital investments (Haldane and Davies, 2011).

Another consequence is that returns on institutional investment are generally low in real terms, because of their concentration in the safest government bonds and company shares. Low real return is a reflection of the very low proportion of institutional funds going into innovation and new capacity creation - a consistent case of nothing ventured and nothing gained. Until 2008, debt securitization provided a potential channel for institutional capital into risky ventures whose debt was bundled with safer ones into AAA securities: but the crisis revealed how easily these bundles could be broken apart, and the same pooling of risks at top investment grade is unlikely to be come possible again (Gonzalez-Paramo, 2010). Perhaps the most damaging consequence is that equity has - for any company that wants to attract institutional investment - become 
functionally more comparable to debt. Managers feel obliged to pay dividends with size and comparable regularity to debt interest payments, and to defend the share price so that equity holders do not face comparably higher capital risk than debt holders. In strategic terms, the growing convergence of equity and debt reduces management's scope to put shareholders' capital at risk through product or process innovation. In corporate-finance terms, it erodes the role of shareholders' equity as a safety margin between assets and liabilities. When shareholders are institutions investing the retirement savings of ordinary citizens, governments do not dare to let them absorb the consequences of widespread asset-price deflation, and are forced to intervene to absorb losses with public funds (Haldane, 2010b; Admati et al, 2010).

\subsection{Return on equity: mis-measuring profit from investment}

For investors in corporate or bank equity, the relevant measure of profit is return on equity: earnings (before interest and taxation) divided by the value of shareholders' equity. Managers of these enterprises are therefore constrained to maximize profit by maximizing return on equity. This can be done by boosting pre-tax profit and/or by reducing equity. Much concern was raised in the 1990s about business practices and accounting techniques which could artificially raise the level of profit, especially in sensitive pre-reporting periods. Distortions due to this incentive, which culminated in the Enron collapse, led to the imposition of tougher corporate codes, notably SarbanesOxley in the US. In the 2000s, this led enterprises - and particularly banks - to pursue increased return on investment through the second option: deliberately (and artificially) reducing the volume and value of equity.

The consistently rising stock markets encountered in Europe, North America and other regions in 2001-8 placed downward pressure on corporate returns on equity (ROE), by raising the value of shareholders' equity. This was exacerbated by changes in accounting convention, especially under International Financial Reporting Standards, which favor the marking-to-market of assets and liabilities, leading to the quicker transmission of rising equity markets to rising shareholders' equity. Publicly listed companies therefore came under pressure to restore ROE by reducing their shareholders' equity, through techniques that included moving assets off the balance sheet, substituting debt for equity and buying-back shares. Privately held companies reacted to similar pressure by running down their reserves, or by floating on stock markets and paying-out the reserves as bonuses to the new shareholders.

Return on investment (ROI), though taking account of increases in debt that may have been used to inflate ROE, is a similarly unreliable guide to value creation. Unproductive investment and unproductive rent-seeking have the common feature of generating a positive private ROI - which can exceed costs of capital - for the people or enterprises that engage in them, while generating no net social return on the investment. The early rent-seeking literature drew attention to large corporations and trusts whose investment in lobbying for entry restriction generated flows of monopoly profit for their shareholders, with implied welfare losses for other stakeholders. Attention has shifted more recently to the financial sector, where most active fund management companies generate profit without giving their investors an excess return over the market portfolio after deducting expenses (e.g. Malkiel, 2004), supporting the widely-held view that pursuit of this 'net alpha' is a zero-sum game (Hill 2006). The social return in both cases is eliminated by the deadweight loss during redistribution from consumer to producers, or by the mutual cancellation of investors' positive and negative ROI. Since those best 
placed to make additional profit through rent-seeking are those who have already accumulated resources through past profit, redistribution is likely to result in a rise in inequality, which may cause further welfare loss (Wilkinson and Pickett, 2009).

The financial crisis served as a reminder that high returns - even if recorded on all measures - may disappear when suitably risk-adjusted. There is now a consensus that financial markets seriously underpriced risk in the decade before the financial crisis (Greenspan, 2008; King, 2012), so that even the 'risk-adjusted' measures of the time overstated the attractiveness of investment in financial firms and in the more financialised non-financial companies. The costs of rescuing the UK financial system after its near-collapse in 2008, which could approach an entire year's GDP when the displacement from trend growth is calculated (Haldane, 2010b), exceed the profits that the sector recorded in 2000-7, suggesting that a return on capital which appeared strongly positive for most of that decade was actually negative (for the economy as a whole, and for private investors until their losses were socialized through government action to buy troubled assets and recapitalize insolvent banks).

High returns (to financial firms and large non-financial companies) may also reflect an element of rent transferred from other sectors, or smaller competitors in the sector, as well as an element of profit from newly created income. Although the long-noted link association between market share and ROI has been attacked as a spurious correlation (Jacobson and Aaker, 1985), the association between industry concentration and ROI has been so long established (e.g. Sullivan, 1977; Buzzell et al 1975) that rates of return and profits have been suggested as an appropriate measure of market power (Kreitzman and Williams, 2008). Monopoly rents extracted from consumers by large retailers, and from business customers by large wholesalers, can be viewed as a redistribution of income between agents (value transfer) which inflicts, on standard welfare analysis, a deadweight loss of national income (value destruction). Even before its recent crisis, the financial sector's growing GDP share, high profit rates and concentration of very high income recipients (especially in the US and UK) had aroused suspicion that it was extracting rents from real-economy businesses, reversing the expectation that more efficient intermediation (after deregulation) would drive financial transaction-costs down.

\section{Conclusion}

The swift reversal of several years' GDP growth by the financial crisis that started in 2008 requires a rethink of the way value-added was measured, both in the financial sector and in the manufacturing and service industries to which it was assumed to have been channeling productive investment. This paper highlights the need to re-introduce concepts of 'value' that were lost in the $20^{\text {th }}$ century reformulation of macroeconomics, and therefore neglected in the national income accounting that it gave rise to. It argues that the sustainability of income flows, and productiveness of investments, can be gauged from their relation to balance-sheet changes. Expenditure that adds to balancesheet assets is potentially productive investment, though real assets are still vulnerable to devaluation through technological obsolescence, and financial assets to devaluation through negative reappraisal by outside investors. Expenditure financed by withdrawal of balance-sheet assets is also potentially productive, but only if it leads to new investment that generates at least equivalent assets elsewhere in the economy. 'What 
went wrong' in the build-up to 2008 can be interpreted as the unproductive use of income made available for investment, compounded by the extraction of much of that income from liquidation of past investment.

The economic 'rebalancing' required after the 2008 financial crisis and subsequent recessions is usually taken to mean a contraction of the public sector (and public borrowing) in favor of expanded private production, and promotion of exports to narrow the current-account deficit and reduce reliance on capital inflows. But unless guided by a clearer viw of what constitutes value, and what distinguishes its creation from its transfer, extraction and destruction, across-the-board promotion of private investment and reduction of public investment could be counterproductive. The absence of value-creation in some forms of private investment (especially those in the financial sector) has been widely noted but is not being clearly reflected in financialsector reform plans, which are narrowly focused on avoiding a recurrence of the conditions that caused the GFC while supporting major banks so that they re-expand business lending. The understatement of value-creation in some forms of private investment (and much public investment) is not fully addressed in new methods to incorporate R\&D into national accounts. This analysis supports a number of policies that contribute to more productive mobilization of private investment - including the recognition that $R \& D$, and other activities conducive to long-term growth, may still be undervalued in revised GDP calculations as well as being undervalued by equity markets (and therefore under-prioritized by public companies); and the need to assign greater priority to R\&D in public and non-profit institutions, and other enterprises not subject to this equity-market bias. This would imply more concrete steps to distinguish borrowing for public investment (in R\&D and infrastructure) from borrowing for public or (financing of) private consumption, when setting limits on fiscal deficits.

The financial crisis has left most of Europe's economies, including the UK, with substantially raised levels of public and private debt which can only be paid-down by making more productive use of a now much-diminished flow of new capital. There are strong empirical reasons for believing that substantial real investment opportunities are becoming available, as a result of technological breakthroughs already made (Perez, 2012). But that their fulfillment will require new forms of enterprise structure, financing and regulation whose creation requires more than the financial-sector reforms currently under way. 


\section{References}

Admati A, DeMarzo P, Hellwig M and Pfleiderer P., (2010), 'Fallacies, irrelevant facts and myths in the discussion of capital regulation: why bank equity is not expensive', Stanford Graduate School of Business Research Paper 2065, 23 March.

Alessandri P \& Haldane A (2009) Banking on the state, Bank of England, November, online at

http://www.bankofengland.co.uk/publications.Documents/speeches/2009/speech040 9.pdf, accessed 20.7.13

Baumol, W. (1990), 'Entrepreneurship: Productive, Unproductive, and Destructive', Journal of Political Economy, University of Chicago Press, vol. 98(5), pages 893-921, October.

BEA (2013) Preview of the 2013 comprehensive revision of the National Income and Product Accounts, Bureau of Economic Analysis, Online at http://www.bea.gov/scb/pdf/2013/03\%20March/0313_nipa_comprehensive_revision _preview.pdf, accessed 17.7.13

Benabou R (1989), 'Optimal price dynamics and speculation with a storable good', Econometrica 57(1), 41-80.

Boaz D and Crane E (1993), Market Liberalism, Washington: Cato Institute.

Buchanan J (1980), 'Rent-seeking and profit-seeking', in J Buchanan, R Tollison and G Tullock (eds) (1980), Towards a theory of the rent-seeking society, Texas AandM Press.

Burlamaqui, L. (2012), 'Knowledge Governance: An Analytical perspective and its Policy Implications' to be published in Burlamaqui, L., Castro, A.C. and Kattel, R. (eds):

Knowledge Governance: Reasserting the Public Interest. Anthem Press.

Buzzell R, Gale B and Sultan R (1975), 'Market share - a key to profitability', Harvard Business Review, January.

CBI (2011), 'A Vision for Rebalancing the Economy', December. London: Confederation of British Industry.

Chan W, Faff R, Gharghori P, Ho Y (2007) The relation between R\&D intensity and future market returns: does expensing vs capitalization matter? Review of Quantitative Financial Economics 29, 25-51.

Ciftci M, Lev B \& Radhakrishnan S (2011) Is R\&D mispriced or properly risk adjusted? Journal of Accounting, Auditing and Finance 26(1), 81-116.

Cosh, A., Hughes, A., Bullock, A. and Milner, I. (2009), 'SME Finance and Innovation in the Current Economic Crisis', Centre for Business Research, University of Cambridge, available at http://www.cbr.cam.ac.uk/pdf/CrCr_EconCrisis.pdf.

Ekelund Rand Tollison R (1981), Mercantilism as a Rent-Seeking Society: Economic Regulation in Historical Perspective. College Station, Texas: Texas A and M University Press.

Florida R (2002) The Rise of the Creative Class, New York: Basic Books 
Gagnon M-A, Lexchin J (2008) The Cost of Pushing Pills: A New Estimate of Pharmaceutical Promotion Expenditures in the United States. PLoS Med 5(1): e1. doi:10.1371/journal.pmed.0050001

Gonzalez-Paramo, J (2010), 'Re-starting securitization, speech to Association for Financial Markets in Europe Conference', 16 June, online at www.ecb.int/press/key/date/2010/html/sp100626.en.html, accessed 24.5.12.

Greenspan A (2008), The Age of Turbulence, London: Penguin.

Haldane A (2010a), 'The contribution of the financial sector: miracle or mirage', paper to Future of Finance conference, London, 14 July.

Haldane A (2010b), 'The \$100bn question, comments at Institute of Regulation and Risk', Hong Kong, 30 March.

Haldane A and Davies R (2011), 'The short and long', paper presented to 29th European Society for Financial Research colloquium, Brussels, 11 May.

Hill, J (2006) Alpha as a net zero sum game: how serious a constraint? Journal of Portfolio Management 32(4) 24-32.

ICB (2011b), Vickers Commission (The Independent Commission on Banking) Final Report, September,. http://bankingcommission.s3.amazonaws.com/wpcontent/uploads/2010/07/ICB-Final-Report.pdf (accessed 14 November 2011).

Irwin N (2013) Huzzah! The US economy is 3 percent bigger than we thought. Thanks, George Lucas!, Washington Post, 22 April.

Jacobson, R.and D. A. Aaker (1985), 'Is market share all that it's cracked up to be?', Journal of Marketing, 49 (Fall), 11-22.

Kay, J (2012) The Kay Review of UK Equity Markets and Long-Term Decisionmaking, Final Report, July, London: Dept of Business, Innovation and Skills,

King, M (2012), The Today Lecture 2012, online at www.bbc.co.uk/today/hi/today/newsid_9718000/9718062.stm, accessed 14.5.12.

Kiyotaki N \& Moore J (2005) Financial deepening, Journal of the European Economic Association 3(2-3), 701-713

Kothari S, Laguerre T \& Leone J (2002) Capitalisation vs expensing: evidence on the uncertainty of future earnings for capital expenditure vs R\&D outlays. Rewview of Accounting Studies 7, 355-382.

Kreitzman K and Williams M (2008), 'Estimating market power with economic profits', Competition Economics LLC Working Paper, 21 July.

Lansley S (2012) The Cost of Inequality, London: Gibson Square

Lazonick, W. (2008), 'The quest for shareholder value: stock repurchases in the US economy', September, mimeo, University of Massachusetts Lowell.

Lazonick W (2009), 'The buyback boondoggle', Business Week, 13 August 
Lazonick, W. and Tulum, O. (2011), 'US Biopharmaceutical Finance and the Sustainability of the Biotech Business Model', Research Policy, vol. 40(9), pp. 1170-1187. Lazonick and Mazzucato (2012), 'The risk-reward nexus in the innovation-inequality relationship', FINNOV Discussion Paper D2.11, March.

Levy S (2013) Changes in real earnings in the UK and London, 2002 to 2013, Office for National Statistics $13 \mathrm{Feb}$, online at http://www.ons.gov.uk/ons/dcp171766_299377.pdf, accessed 17.7.13 Lewitt M (2010), The Death of Capital, New York: Wiley.

Light D \& Lexchin R (2012) Pharmaceutical research and development: what do we get for all that money? British Medical Journal 235:e4348, 7 August

McKinnon R (1973) Money and Capital in Economic Development, Brookings Institution Malkiel B (2004), 'Can predicatble patterns in market returns be exploited using real money?', Journal of Portfolio management, 131-41.

Mazzucato, M. (2011), The Entrepreneurial State, Demos.

Mazzucato, M. and Tancioni, M. (2012), 'Stock Price Volatility, Patents and R\&D: the case of the pharmaceutical industry', forthcoming Journal of Evolutionary Economics.

Miles, D. (1993), 'Testing for short termism in the UK stock market', Economic Journal 103(421).

Mulgan G (1997) Connexity: How to live in a connected world, London: Vintage Leadbeater, C (2000) Living on Thin Air: The new economy, London: Penguin Coyle, D (1999) The Weightless World, London: Capstone

Nakamura L (2008) Intangible assets and national income accounting, Federal Reserve Bank of Philadelphia Working Paper 08-23, 6 October

NESTA (2009), The Vital 6\%, http://www.nesta.org.uk/events/assets/features/the_vital_6_per_cent.

OECD (2010a), 'Rebalancing the economy', Economic Surveys: United States, Vol 2010(15), September, 49-79.

OECD (2010b), 'Rebalancing the economy', Economic Surveys: Spain, Vol 2010(19), December, 21-55.

OECD (2011), 'Supporting the recovery and rebalancing the econom'y, Economic Surveys: UK, Vol 2011 (3), March, 21-51.

Pearce, D.W. and Warford, J. (1993), World Without End: Economics, Environment and Sustainable Development, Oxford University Press, Oxford.

Perez C (2012), 'Financial crises, bubbles and the role of government in unleashing golden ages', FINNOV Discussion Paper D2.12, January.

PwC (2010) Accounting for Innovation, London: PricewaterhouseCoopers.

Romer, P. M. (1994). "The Origins of Endogenous Growth". The Journal of Economic Perspectives 8 (1):3 
Schumpeter, J. (1942/1992), Capitalism, Socialism and Democracy, Routledge.

Scott, M.FG (1989), A New View of Economic Growth, Oxford: Oxford University Press. Shaikh A \& Tonak E (1994) Measuring the Wealth of Nations, Cambridge: Cambridge University Press.

Shaw E (1973) Financial Deepening in Economic Development, Oxford: Oxford University Press.

Shiller R (2005), Irrational Exuberance, Princeton University Press.

Stiglitz J (2013) The Price of Inequality, New York: Norton

Stone, R (1984), 'The accounts of society', Nobel memorial lecture, 8 December, 1984.

Sullivan T (1977), 'A note on market power and returns to stockholders', Review of Economics and Statistics 59(1) 108-113.

Thurow L (1975), Generating Inequality, NY: Basic Books.

Tsoligkas F \& Tsalavoutas I (2011) Value relevance of R\&D in the UK after IFRS mandatory implementation, Applied Financial Economics 21, 957-967.

Turner A (2009), The Turner Review, London: Financial Services Authority.

Turner A (2012) Economics After the Crisis, Cambridge MA: MIT Press

UKCES (2011), Rebalancing the Economy Sectorally and Spatially: an evidence review, Volume 1, Evidence Report 33, August, London: UK Commission for Employment and Skills.

Vlachos J and Waldenstrom D (2005), International financial liberalization and industry growth, International Journal of Finance and Economics 10(3), 263-284.

Wasshausen D \& Moulton B (2006) The role of hedonic methods in measuring real GDP in the United States, paper to $31^{\text {st }}$ CEIES Seminar, Rome, October; online at http://www.bea.gov/papers/pdf/hedonicGDP.pdf, accessed 17.7.13

Wilkinson R and Pickett W (2009), The Spirit Level, London: Allen Lane. 


\section{Recent papers in the SPRU Working Paper Series:}

SWPS 2013-01. Gabriele Pellegrino and Maria Savona. September 2013. "Is money all? Financing versus knowledge and demand constraints to innovations".

SWPS 2013-02. Adrian Smith and Sabine Hielscher. September 2013. “Grassroots digital fabrication and makerspaces: reconfiguring, relocating and recalibrating innovation".

SWPS 2013-03. Paul Nightingale and Alex Coad. September 2013. "Muppets and gazelles: political and methodological biases in entrepreneurship research".

SWPS 2013-04. Alberto Marzucchi and Sandro Montresor. September 2013. "The multidimensional additionality of innovation policies. A multi-level application to Italy and Spain".

SWPS 2013-05. Fulvio Castellacci. September 2013. "Institutional voids or entry barriers? Business groups, innovation and market development in emerging economies".

SWPS 2013-06. Tommaso Ciarli and Michele Di Maio. October 2013. "Theoretical arguments for industrialisation-driven growth and economic development".

SWPS 2013-07. William Lazonick, Mariana Mazzucato, and Öner Tulum. October 2013. “Apple's changing business model: what should the world's richest company do with all those profits?".

SWPS 2013-08. Phil Johnstone. October 2013. "Planning reform, rescaling, and the construction of the post-political: The case of The Planning Act 2008 and nuclear power consultation in the UK".

\section{SPRU}

Science and Technology

Policy Research
SPRU

Science and Technology Policy Research

University of Sussex

Falmer, Brighton, BN1 9SL, UK

www.sussex.ac.uk/spru 